\title{
Analysis Of Low Birth Weight (LBW) Infants Events Based On Parity Of Mother In RSUD Dr. H. Moch Anshari Saleh Banjarmasin
}

\author{
Nita Hestiyana ${ }^{1}$, Susanti Suhartati ${ }^{2}$ \\ \{nitahestiyana@gmail.com ${ }^{1}$, suhartatisusanti@gmail.com ${ }^{2}$ \} \\ Diploma Three Midwifery Health of Faculty Sari Mulia University, Pramuka Street no.2 \\ Banjarmasin, South Kalimantan ${ }^{1,2}$
}

\begin{abstract}
The main cause of high infant mortality is Low Birth Weight (LBW). One of the factors LBW is parity of mother. In Ansari Saleh Hospital, case of LBW in 2017 were 33\%. This study using a case control approach. The sample of cases was LBW, control was normal birth weight. The sample of cases using minimum sample is 30 and control is 60 (ratio 1:2) and using sytematic random sampling. The analysis using chi square test. There was a relationship between parity of mother with incidence of LBW (p value 0,001 ), OR 5.182 which means that mothers with risky parity have a 5x chance of giving birth to LBW compared to mothers with no risk of parity. Mothers who have risk parity during pregnancy are expected to be more routine in carrying out pregnancy examinations so that the incidence of LBW and the others can be detected and treated early.
\end{abstract}

Keywords: Low Birth Weight, Parity

\section{Introduction}

The mortality rate is an indicator of the success of a country's health service system, while the maternal mortality rate (MMR) is an indicator in the obstetric field. The maternal mortality rate is also one of the targets set in the Sustainable Development Goals (SDGs) goal, which is the third goal, which is to ensure a healthy life and encourage welfare for all people by reducing maternal mortality to below 70 per 100,000 births. live and end preventable infant and toddler deaths, by trying to reduce the Neonatal Mortality Rate by at least 12 per $1,000 \mathrm{KH}$ and the Under-five Mortality Rate of 25 per 1,000 KH [1].

Most causes of infant death are due to emergencies and complications during neonatal period, one of which is babies born with birth weight less than 2500 grams. The incidence of babies born with low birth weight is a serious problem, because it affects the high morbidity and infant mortality rate. Babies born with low birth weight are at risk of experiencing obstacles in growth and development, and can cause death. The risk of death of babies with low birth weight (LBW) is higher compared to babies born with normal body weight or more than 2500 grams [2]. 
LBW is a baby born with a birth weight of less than 2,500 grams regardless of the period of pregnancy. About $15.5 \%$ of all births in the world are born with low birth weight. The majority of LBW $(95.6 \%)$ are from developing countries [3]. The LBW frequency in developed countries ranges from $3.6-10.8 \%$, in developing countries $10-43 \%$. LBW is still a problem in the field of health, especially perinatal health. In Indonesia alone, the LBW percentage is $10.2 \%$ [4].

LBW is influenced by two factors, namely maternal factors and fetal factors. Maternal factors that influence LBW incidence are maternal age during pregnancy ( $<20$ years or $>35$ years and the distance between labor and pregnancy is too short), maternal condition (history of parity, socioeconomic circumstances including maternal education). Age, number of parities, pregnancy spacing, weight gain, anemia and pre-eclampsia have a significant effect on LBW [5]. Parity is the number of deliveries experienced by mothers before labor or pregnancy now. Generally, LBW increases with increasing maternal parity. The risk for LBW is high in the first parity and then decreases in the second or third parity, then increases again in the fourth parity.

The results showed that parity is a significant risk factor for LBW events so that mothers with parity of more than 3 children are 2.4 times at risk of having a baby with LBW [6].

Regional General Hospital (RSUD) Dr. H. Moch. Ansari Saleh Banjarmasin is the first referral hospital in Banjarmasin. Based on the results of a preliminary study the incidence of LBW in 2017 amounted to 223 (33.33\%) infants experiencing LBW from 669 babies born [7].

\section{Research Methods}

The study was conducted in the VK room Dr. H. Moch. Ansari Saleh Banjarmasin, South Kalimantan. The time approach method used in this study is the case control time approach. This study aims to look at the incidence of LBW using case control. The population in this study were all newborns in the VK room Dr. H. Moch. Ansari Saleh Banjarmasin period from January 1, 2017 to December 31, 2017. Babies born in LBW in that period amounted to 223 people while newborns with normal weight totaled 446 babies. The sample used is a ratio of 1: 2 the total cases use a minimum sample of 30 while the control sample is 60 . The sampling technique uses systematic random sampling

\section{Result and Analysis}

Univariate analysis is carried out to analyze each variable of the research results presented descriptively by calculating the frequency distribution. The results of the study in the delivery room at Moch Ansari Saleh Hospital in Banjarmasin on the analysis of the incidence of low birth weight babies (LBW) based on maternal parity at RSUD Dr. H. Moch. Ansari Saleh Banjarmasin In 2017 there were 90 samples. Univariate analysis was carried out to determine the data management which was carried out manually and entered in the table to find out the distribution of each variable, namely LBW events and maternal parity as follows: 


\subsection{Univariate Analysis}

a. LBW incidence

The distribution of LBW and not LBW incidents in RSUD Dr. H Moch Ansari Saleh Banjarmasin is as follows:

Table 1. Distribution of Frequency of LBW in RSUD Dr. H. Moch. Ansari Saleh Banjarmasin

\begin{tabular}{cccc}
\multirow{2}{*}{ No. } & Low Birth Weight & \multicolumn{2}{c}{} \\
\cline { 3 - 4 } & & $\mathrm{n}$ & $\%$ \\
\hline 1 & LBW $(<2.500$ grams $)$ & 30 & 33,3 \\
\cline { 2 - 4 } 2 & Not LBW $(\geq 2.500$ grams $)$ & 60 & 66,7 \\
\hline & $\mathrm{N}$ & 90 & 100 \\
\hline
\end{tabular}

Based on table 1 it was found that the LBW incidence was 30 samples (33.3\%) and not LBW was $60(66.7 \%)$.

b. Parity of mother

Parity distribution of risky and non-risk mothers in Dr. H Moch Ansari Saleh Banjarmasin Hospital is as follows:

Table 2. Frequency Distribution Parity of mother at RSUD Dr. H. Moch. Ansari Saleh Banjarmasin

\begin{tabular}{cccc}
\hline \multirow{2}{*}{ No } & \multicolumn{3}{c}{ Parity of Mother } \\
\cline { 2 - 4 } & & $\mathrm{n}$ & $\%$ \\
\hline 1 & Risk & 34 & 37,8 \\
2 & $(1$ dan $>3)$ & 56 & 62,2 \\
\hline & Not at risk $(2$ dan 3$)$ & 90 & 100
\end{tabular}

Based on table 2, it is found that the most percentage, namely parity, is not as much risk 56 samples (62.2\%).

\subsection{Bivariate Analysis}

Bivariate analysis aims to analyze the differences between the research variables and analyzed using computerized aids with significance level $\alpha=0.05$. In the bivariate analysis an independent variable that is parity of the maternity mothers will be associated with the dependent variable which is the incidence of LBW. Analysis of data processed statistically using the chi square test to see the correlation between the dependent variable and the independent variable.

Analysis of the incidence of low birth weight babies (LBW) based on Maternity Parity in RSUD Dr. H. Moch Ansari Saleh Banjarmasin. 
Table 3. Analysis of the incidence of low birth weight babies (LBW) based on the parity of mother in RSUD Dr. H. Moch Ansari Saleh Banjarmasin

\begin{tabular}{|c|c|c|c|c|c|c|c|c|c|}
\hline \multirow{3}{*}{ No } & \multirow{3}{*}{ Parity } & \multicolumn{4}{|c|}{ LBW incident } & \multirow{2}{*}{\multicolumn{2}{|c|}{$\mathrm{n}$}} & \multirow{3}{*}{$\begin{array}{c}\mathrm{P} \\
\text { Valu } \\
\mathrm{e}\end{array}$} & \multirow{3}{*}{$\begin{array}{l}\mathrm{O} \\
\mathrm{R}\end{array}$} \\
\hline & & \multicolumn{2}{|c|}{ LBW } & \multicolumn{2}{|c|}{ Not LBW } & & & & \\
\hline & & $\mathrm{F}$ & $\%$ & $\mathrm{~F}$ & $\%$ & $\mathrm{~F}$ & $\%$ & & \\
\hline 1 & Risk $(1$ dan $>3)$ & 19 & 63,3 & 15 & 25 & 34 & 37,8 & & \\
\hline 2 & $\begin{array}{c}\text { Not at risk (2 dan } \\
3)\end{array}$ & 11 & 36,7 & 45 & 75 & 56 & 62,2 & 0,001 & $\begin{array}{l}5,1 \\
82\end{array}$ \\
\hline & $\mathrm{N}$ & 30 & 100 & 60 & $\begin{array}{c}10 \\
0\end{array}$ & 90 & 100 & & \\
\hline
\end{tabular}

Based on table 3 chi square correlation test was performed to prove the hypothesis obtained $\mathrm{p}$ value $=0.001 \alpha(0.05)$ so Ho was rejected and Ha was accepted, it can be explained there is a relationship between maternal parity with the incidence of low birth weight babies (LBW) in Dr. H. Moch Ansari Saleh Banjarmasin. OR value of 5.182 means that mothers with risk parity have a $5 \mathrm{x}$ chance of giving birth to low birth weight babies compared to mothers with no risk parity

\section{Discussion}

Based on research conducted at Dr. H. Moch Ansari Saleh Banjarmasin regarding Analysis of Low Birth Weight (BBLR) based on Maternity Parity in the VK room Dr. H. Moch Ansari Saleh Banjarmasin obtained the following results: based on the results of data analysis, it was found that the most LBW events occurred at risk parity $19(63.3 \%)$ while the highest LBW events did not occur at $45 \%$ (75\%) non-risk parity. Chi square correlation test to prove the hypothesis was tested with the results obtained $\mathrm{p}$ value $=0,001 \alpha \alpha(0.05)$ so Ho was rejected and Ha accepted, it can be explained that there is a relationship between maternal parity with the incidence of low birth weight (LBW) in Dr. H. Moch Ansari Saleh Banjarmasin. The OR value is 5.182 which means that mothers with parity are at a $5 \mathrm{x}$ chance of giving birth to low birth weight babies compared to mothers with no-risk parity.

Research by Yuijin et al (2019) titled Impact of Changes in Maternal Age and Parity Distribution on Increasing Trends in the Low Birth Weight and Very Low Birth Weight Rates in South Korea, 2005-2015 shows that parity contributes to an increase in LBW incidence [8]

Several studies have shown that the second and third births are the safest. This is because the risk of serious complications, such as bleeding and infection increases significantly from the fourth birth onwards, so there is a tendency for babies to be born with LBW conditions and even for maternal and infant deaths.

Research Negi et al (2006) with the title Epidemiological Factors Affecting Low Birth Weight shows that parity is one of the factors associated with LBW events. High parity status can increase the risk of LBW and stillbirth. This happens because the higher the parity status, the ability of the uterus to provide nutrients for the next pregnancy decreases so that the distribution of nutrients between the mother and fetus is disrupted which can ultimately lead to LBW [9]. 
The results of this study are consistent with the theory that it is said that one of the causes of LBW from maternal factors is parity 1 or $\geq 4$. High parity will have an impact on the emergence of various health problems for both mothers and babies born. Repetitive pregnancy and childbirth cause damage to blood vessels in the uterine wall and deterioration of tissue elasticity that has been repeatedly stretched out of pregnancy so that it tends to cause abnormalities or abnormalities in placental growth and fetal growth so as to give birth to low birth weight babies [10].

\section{Conclusion}

Based on the results of the test, there was a relationship between parity of mother with the incidence of LBW ( $\mathrm{p}$ value 0,001 ), OR 5.128 which means that mothers with risky parity have a $5 \mathrm{x}$ chance of giving birth to LBW compared to mothers with no risk of parity. Mothers who have risk parity during pregnancy are expected to be more routine in carrying out pregnancy examinations so that the incidence of LBW and the others can be detected and treated early.

\section{Acknowledgments}

The autors wish to express gratitude to the Dr. H. Moch. Ansari Saleh Banjarmasin who has facilitated conducting research. Thank you do not forget to say to colleagues and families who have supported researchers and to all those who can not be mentioned one by one.

\section{References}

[1] Kementerian Kesehatan RI. Kesehatan dalam Kerangka Sistainable Development Goals (SDG'S). Jakarta: Kementerian Kesehatan RI (2015)

[2] Manuaba, I .B .G. Ilmu Kebidanan, Penyakit Kandungan \& Keluarga Berencana Untuk Pendidikan Bidan. Jakarta: ECG (2013)

[3] WHO. Statistic of low birth weight infants in low and middle income countries. http://www.who.int. [Di akses pada tanggal 12 Agustus 2019]. (2014)

[4] Kemenkes RI. Profil Kesehatan Indonesia tahun 2014. Jakarta : Kemenkes RI (2015)

[5] Sulistyorini, \& Siswoyo, S. Analisis faktor-faktor yang mempengaruhi kejadian BBLR di Puskesmas kabupaten Banjarnegara. J Unimus. 1:1-6 diunduh 20 Agustus 2019 (2012)

[6] Joeharno. Berat Badan Lahir Rendah (BBLR) : Beberapa faktor risiko kejadian bblr di Rumah Sakit Al fatah ambon periode Januari - Desember Tahun 2006 (2008).

[7] Diklat RSUD dr. H. Moch. Ansari Saleh Banjarmasin (2018).

[8] Yuijin oh, Jisuk Bae. Impact of Changes in Maternal Age and Parity Distribution on the Increasing Trendsin the Low Birth Weight and Very Low Birth Weight Rates in South Korea, 2005-2015. Journal of Preventive Medicine \& Public Health 2019; 52(2): 123-130. (2019)

[9] Negi, Karan \& Kandpal, S.D. \& Kukreti, M. Epidemiological Factors Affecting Low Birth Weight. JK Science : Journal of Medical Education \& Research. 8. (2006)

[10] Wiknjosastro. Ilmu Kebidanan Edisi Ketiga Cetakan Keempat. Jakarta: YBPSP (2012). 